\title{
SPATIAL DIFFERENTIATION OF CHILD WELL-BEING IN EUROPE
}

\section{Dorota Strózik, Ph.D.}

Poznań University of Economics

Faculty of Economics

Department of Statistics and Demography

Al. Niepodległości 10, 61-875 Poznań, Poland

e-mail:dorota.strozik@ue.poznan.pl

Tomasz Strózik, Ph.D.

Poznań University of Economics

Faculty of Commodity Science

Department of SBusiness Activity

Al. Niepodległości 10, 61-875 Poznań, Poland

e-mail: tomasz.strozik@ue.poznan.pl

Received 21 January 2014, Accepted 8 July 2014

\begin{abstract}
An important determinant of the level of development of each country and the whole Europe is the care about an adequate level of well-being and quality of life of all citizens, above all those to whom the future belongs - our children. In the times of demographic changes it is particularly important to understand specific needs and rights of the youngest generation of Europeans. Investing in children is investing in our future, the shape of which will depend precisely on whether the youngest generation will be healthy, welleducated and able to participate in the development of their societies. The aim of this study is to identify territorial differentiation of children's well-being in Europe at the end of the first decade of the 21st century using the methods of multivariate data analysis. The study was based on data published by Eurostat (among others EU-SILC), OECD (PISA), UNICEF, WORLD BANK and WHO (HBSC) for the years 2009 and 2010.
\end{abstract}

Keywords: children, well-being, Europe, regional differentiation, taxonomy.

JEL classification: C38, J13. 


\section{Introduction}

One of the symptoms of a high standard of development of each country and the whole Europe is the care about ensuring an adequate level of well-being and quality of life to all citizens, and above all to those who will soon decide about the future-our children. In the times of demographic changes the lack of understanding for specific needs and rights of the youngest generation of Europeans may bring about negative consequences. Investing in children means investing in the future of us all, the future whose shape will depend exactly on whether the young generation will be healthy, educated, capable and ready to participate in the development of their societies.

Taking into account disproportions in the regional development of Europe, it is necessary to indicate the most important areas determining differentiation of well-being of the youngest in particular countries, to undertake activities allowing to eliminate the diagnosed differences and to continuously monitor the effects of those activities.

The aim of this study is an attempt to identify and evaluate territorial differentiation of child well-being in the countries of Europe at the end of the first decade of the 21st century.

Studies on the well-being of such a specific group as children are a difficult task due to the lack of uniform terminology. Moreover, a discussion is still going on about what should be understood under the term well-being or quality of life and about how to measure those categories.

The subject of this analysis is children understood as the total number of people below eighteen years of age ${ }^{1}$. For the needs of this article, well-being was identified as resources and factors determining satisfaction of the basic needs of children in the short and long-term perspective along with evaluation of the level of satisfaction of those needs. The authors distinguished four crucial aspects of the life of the youngest, such as: material and housing conditions, health and safety, education, and behaviours and risks ${ }^{2}$.

\section{Source data}

Child well-being should be regarded as a complex, interdisciplinary and directly nonmeasurable category. Therefore, in order to accomplish the research aims, the authors prepared a data base containing 39 indicators which characterize different aspects of children's life in the chosen countries of Europe. The source material was data published by Eurostat (among others EU-SILC), OECD (PISA), UNICEF, WORLD BANK and WHO (HBSC) for the years 2009 and 2010 (Table 1). 
The indicators concerning child well-being gathered in the data base were grouped, in line with the accepted methodology, according to four dimensions.

The first dimension comprises indicators characterizing material (economic) conditions of the life of children and their families together with their housing situation - the key indicators for other aspects of life. The second dimension represents widely understood health (both physical and mental) and the sense of security (physical and emotional). A separate group is the factors which illustrate satisfaction of the children's needs concerning such an important sphere of their life as education (including the so-called early education) perceived from the viewpoint of both participation and achievement. The last area defined as "behaviours and risks" includes the set of habits and behaviours of positive (e.g. proper eating habits, physical activity) and negative nature (using stimulants) which influence life quality of the youngest in the longer perspective (Table 1).

Table 1. Indicators of child well-being

\begin{tabular}{|c|c|c|}
\hline Code & Indicator & Data Source \\
\hline 1 & 2 & 3 \\
\hline$X_{11}$ & Children at risk of poverty or social exclusion $(\%)$ & Eurostat 2010 \\
\hline$X_{12}$ & Children aged 0-17 years living in jobless households (\%) & Eurostat 2010 \\
\hline$X_{13}$ & Indicator of the low level of family affluence $(\%)$ & HBSC 2010 \\
\hline$X_{14}$ & Children overcrowding rate $(\%)$ & Eurostat 2010 \\
\hline$X_{15}$ & Severe housing deprivation $(\%)$ & Eurostat 2010 \\
\hline$X_{16}$ & Relative median poverty risk gap, age $0-17(\%)$ & SILC 2010 \\
\hline$X_{17}$ & Average number of rooms per person in households with dependent children & SILC 2010 \\
\hline$X_{21}$ & Young people not living with both parents $(\%)$ & HBSC 2010 \\
\hline$X_{22}$ & Fifteen-year olds feeling depressed more than once per week $(\%)$ & HBSC 2010 \\
\hline$X_{23}$ & Fifteen-year olds with problem of overweight and obesity, WHO growth reference (\%) & HBSC 2010 \\
\hline$X_{24}$ & Fifteen-year olds been bullied at school at least once in the past couples of months (\%) & HBSC 2010 \\
\hline$X_{25}$ & Fifteen-year olds who rate their health as fair or poor $(\%)$ & HBSC 2010 \\
\hline$X_{26}$ & Under-five mortality rate (per 1000 live births) & Eurostat 2010 \\
\hline$X_{27}$ & Infant mortality rate (per 1000 live births) & Eurostat 2010 \\
\hline$X_{28}$ & Neonatal mortality rate (per 1000 live births) & Eurostat 2010 \\
\hline$X_{29}$ & $\begin{array}{l}\text { Children aged less than two years old immunised against Diphtheria, Tetanus } \\
\text { and Pertussis }(\%)\end{array}$ & OECD 2010 \\
\hline$X_{210}$ & Children aged less than two years old immunised against Measles (\%) & OECD 2010 \\
\hline$X_{211}$ & Low birth weight rate $(\%)$ & OECD 2010 \\
\hline$X_{31}$ & Fifteen-year olds who like school very much (\%) & HBSC 2010 \\
\hline$X_{32}$ & Fifteen-year olds who feel pressured by schoolwork (\%) & HBSC 2010 \\
\hline$X_{33}$ & Fifteen-year olds who report good or very good perceived school performance $(\%)$ & HBSC 2010 \\
\hline$X_{34}$ & Pupil-teacher ratio in primary education & Eurostat 2010 \\
\hline$X_{35}$ & Participation in early childhood education (\%) & Eurostat 2010 \\
\hline$X_{36}$ & Average class size (ISCED 1) & Eurostat 2010 \\
\hline$X_{37}$ & Children aged less than three years old with no formal childcare $(\%)$ & Eurostat 2010 \\
\hline$X_{38}$ & Average result of test in mathematics & PISA 2009 \\
\hline
\end{tabular}




\begin{tabular}{|c|l|l|}
\hline 1 & \multicolumn{1}{|c|}{2} & \multicolumn{1}{|c|}{3} \\
\hline$X_{39}$ & Average result of test in science & PISA 2009 \\
\hline$X_{310}$ & Average result of test in reading & PISA 2009 \\
\hline$X_{311}$ & $\begin{array}{l}\text { NEET rate - young people aged 15-19 not in employment and not in any education } \\
\text { and training (\%) }\end{array}$ & Eurostat 2010 \\
\hline$X_{41}$ & $\begin{array}{l}\text { Fifteen-year olds spending time with friends after school on four or more days per } \\
\text { week (\%) }\end{array}$ & HBSC 2010 \\
\hline$X_{42}$ & Fifteen-year olds physically active for two or more hours per week (\%) & HBSC 2010 \\
\hline$X_{43}$ & Fifteen-year olds playing PC or console games for two or more games on weekdays (\%) & HBSC 2010 \\
\hline$X_{44}$ & Fifteen-year olds smoking cigarettes at least once a week (\%) & HBSC 2010 \\
\hline$X_{45}$ & Fifteen-year olds drinking beer at least once a week (\%) & HBSC 2010 \\
\hline$X_{46}$ & Fifteen-year olds drinking alcohol at least once a week (\%) & HBSC 2010 \\
\hline$X_{47}$ & Fifteen-year olds who eat breakfast every school day (\%) & HBSC 2010 \\
\hline$X_{48}$ & Adolescent fertility rate (number of births per 1000 women aged 15-19) & WB 2010 \\
\hline$X_{49}$ & Fifteen-year olds eating fruit every day (\%) & OECD 2010 \\
\hline$X_{410}$ & Fifteen-year olds eating vegetable every day (\%) & OECD 2010 \\
\hline
\end{tabular}

Source: own collation.

\subsection{Diagnostic variables}

Taking into account a complex nature of the studied phenomenon, i.e. child well-being, the conducted analyses were based on taxonomic methods which allowed to analyze objects (in this case the countries of Europe) in a multi-feature space ${ }^{3}$.

Table 2. Diagnostic variables of child well-being

\begin{tabular}{|c|l|}
\hline Code & \multicolumn{1}{|c|}{ Variable } \\
\hline$X_{1}$ & Children aged 0-17 years living in jobless households (\%) \\
$X_{2}$ & Indicator of the low level of family affluence (\%) \\
\hline$X_{3}$ & Young people not living with both parents (\%) \\
$X_{4}$ & Fifteen-year olds feeling depressed more than once a week (\%) \\
$X_{5}$ & Infant mortality rate (per 1000 live births) \\
\hline$X_{6}$ & Fifteen-year olds who like school very much (\%) \\
$X_{7}$ & Fifteen-year olds who feel pressured by schoolwork (\%) \\
$X_{8}$ & Pupil-teacher ratio in primary education \\
$X_{9}$ & Participation in early childhood education (\%) \\
$X_{10}$ & Average result of PISA test in mathematics \\
\hline$X_{11}$ & Fifteen-year olds physically active for two or more hours per week (\%) \\
$X_{12}$ & Fifteen-year olds playing PC or console games for two or more games on weekdays (\%) \\
$X_{13}$ & Fifteen-year olds drinking beer at least once a week (\%) \\
$X_{14}$ & Fifteen-year olds eating fruit every day (\%) \\
\hline
\end{tabular}

Source: own collation. 
A significant assumption of the multidimensional comparative analysis methods is to limit the number of diagnostic variables. A too numerous set of characteristics frequently makes it difficult or even impossible to classify the studied objects. This is why a potential, frequently wide set of variables must be subject to selection due to a number of formal criteria ${ }^{4}$.

Making a selection of the final set of diagnostic variables, the authors first of all verified the collected data from the viewpoint of contents, evaluating their credibility and completeness. The next step was to select indicators according to the level of their internal differentiation. From the set of potential diagnostic variables the authors removed those for which the value of variation coefficient (CV) did not exceed the assumed level of 10\%. These features were regarded as quasi-constant, without discriminating qualities. The last stage of selecting variables was to limit excessive correlation of the features representing the same groups of needs. Selection of representatives of these groups was made by means of Z. Hellwig's parametric method ${ }^{5}$. This procedure made it possible to select central and isolated variables representing the four areas of children's living conditions differentiated in the study. In this way the final set of fourteen diagnostic variables was established (Table 2).

\section{Differentiation of children's well-being in Europe}

An attempt to identify spatial differentiation in child well-being in Europe was made using taxonomic methods of multivariate data analysis. At the first stage of comparative analysis, the authors used an indicator approach to the research into complex phenomena, consisting in aggregating the set of diagnostic variables in order to obtain a synthetic measure ${ }^{6}$. Further on the same set of diagnostic variables was used to classify the European countries according to their similarities as regards child well-being.

\subsection{Synthetic measures of child well-being}

The idea in a vast majority of methods used to construct synthetic measures is the same. Values $x_{i}$ of all $n$ features of $X_{1}, X_{2}, \ldots, X_{n}$ representing the studied phenomenon are interpreted as points in $n$-dimensional space $R^{n}$. The essence of these methods is reduced to transformation of the units described by means of many variables into one-dimensional space, obtaining the so-called synthetic variable, which decidedly facilitates classification and comparison of the studied objects. There are many various methods of creating pattern and non-pattern synthetic variables. The idea of pattern methods consists in the fact that in space $R^{n}$ point $x^{*}$ called 
"pattern" is differentiated. The synthetic measure of a unit characterized by the vector of value $x$ is then defined as a function of distance $d\left(x, x^{*}\right)$ of vector $x$ from an established point of reference $x^{*}$. Non-pattern methods (on the other hand) are reduced to calculating average values of vector $x$ components $^{7}$.

The basis to create the so-called synthetic measure of child well-being was the previously defined set of fourteen diagnostic variables (Table 2). Analysis of the direction of impact of the chosen variables on a given phenomenon made it possible to include the following features in the set of stimulants:

$$
\mathrm{S}:\left\{X_{6}, X_{9}, X_{10}, X_{11}, X_{14}\right\}
$$

whereas the following variables were regarded as de-stimulants:

$$
\text { D: }\left\{X_{1}, X_{2}, X_{3}, X_{4}, X_{5}, X_{7}, X_{8}, X_{12}, X_{13}\right\} \text {. }
$$

For the sake of uniformity in the direction of impact of the features used in the study on the level of child well-being and in order to ensure their additivity and comparability, appropriate transformations were made according to two variants. In the first variant normalization was performed according to the formula proposed by D. Strahl ${ }^{8}$. The second variant was based on quotient transformation ${ }^{9}$.

Values $z_{i}$ of synthetic measure $Z$ illustrating child well-being for $i$-country were calculated as a mean arithmetic value of synthetic variables $z_{i q}(q=1, \ldots, 4)$ determined for the spheres of children's life included in the study, with each of those spheres considered as equally significant. Values $z_{i q}$ were calculated as a mean arithmetic value of the normalized values of diagnostic variables.

Finally, two variants of the synthetic measures of children's well-being in particular European countries at the end of the first decade of the 21 st century were obtained (Table 3 ). As a result of sorting and ranking of the obtained values, slightly different classifications were received, depending on the applied variant of synthetic measure $\left(z_{i}\right.$ and $\left.z_{i}{ }_{i}\right)$. The analysis of conformity of the obtained results of classification based on the value of Spearman's rank correlation coefficient ( $p=0.9794$ ) confirmed their high convergence. Thus the selection of the method of normalization did not influence the conducted linear ordering in any significant way.

Having analyzed the obtained results, the authors stated that the most favorable living conditions of children were found in the countries from outside the EU (Iceland, Norway, Switzerland) and also the Netherlands and Slovenia - the only country from the so-called New Union which found itself on the top of the ranking. In the remaining new EU countries child 
well-being is much worse. The most difficult situation is in Romania and the Baltic states. In this respect the countries of Central Europe and Great Britain are characterized by only slightly better conditions.

Table 3. Synthetic measures of child well-being and ranks for particular European countries

\begin{tabular}{|c|c|c|c|c|c|c|c|c|c|}
\hline \multirow{2}{*}{ Country } & \multicolumn{4}{|c|}{$\begin{array}{c}\text { Variant of synthetic } \\
\text { variable } Z\end{array}$} & \multirow{2}{*}{ Country } & \multicolumn{4}{|c|}{$\begin{array}{c}\text { Variant of synthetic } \\
\text { variable } Z\end{array}$} \\
\hline & $z_{i}$ & $\begin{array}{c}\text { rank } \\
(1)\end{array}$ & $z_{i}^{\prime}$ & $\begin{array}{l}\text { rank } \\
(2)\end{array}$ & & $z_{i}$ & $\begin{array}{c}\text { rank } \\
(1)\end{array}$ & $z_{i}^{\prime}$ & $\begin{array}{l}\text { rank } \\
(2)\end{array}$ \\
\hline Iceland & 0.793 & 1 & 2.535 & 1 & Belgium & 0.505 & 15 & 1.116 & 15 \\
\hline Norway & 0.654 & 2 & 1.832 & 2 & Italy & 0.485 & 16 & 1.022 & 18 \\
\hline Netherlands & 0.628 & 3 & 1.575 & 4 & Spain & 0.481 & 17 & 1.054 & 16 \\
\hline Slovenia & 0.622 & 4 & 1.517 & 6 & Greece & 0.478 & 18 & 1.047 & 17 \\
\hline Switzerland & 0.616 & 5 & 1.608 & 3 & Hungary & 0.472 & 19 & 0.956 & 20 \\
\hline Luxembourg & 0.607 & 6 & 1.574 & 5 & Poland & 0.462 & 20 & 0.995 & 19 \\
\hline Finland & 0.597 & 7 & 1.500 & 7 & Slovakia & 0.446 & 21 & 0.937 & 22 \\
\hline Denmark & 0.596 & 8 & 1.391 & 8 & Czech Republic & 0.434 & 22 & 0.942 & 21 \\
\hline Austria & 0.559 & 9 & 1.303 & 10 & UK & 0.428 & 23 & 0.898 & 23 \\
\hline Sweden & 0.556 & 10 & 1.338 & 9 & Lithuania & 0.425 & 24 & 0.876 & 26 \\
\hline Germany & 0.544 & 11 & 1.210 & 13 & Latvia & 0.422 & 25 & 0.897 & 24 \\
\hline Portugal & 0.544 & 12 & 1.249 & 11 & Estonia & 0.416 & 26 & 0.893 & 25 \\
\hline France & 0.532 & 13 & 1.212 & 12 & Romania & 0.357 & 27 & 0.750 & 27 \\
\hline Ireland & 0.514 & 14 & 1.131 & 14 & & & & & \\
\hline
\end{tabular}

$z_{i}-\mathrm{SM}$ value with D. Strahl's normalization.

$z_{i}{ }_{i}-$ SM value with T. Grabiński's normalization.

Source: own calculations.

Poland ranks 19th or 20th in the obtained specification (depending on the accepted synthetic measure) with child well-being below the European average. The situation of Polish children was particularly bad as regards the fourth sphere of their life distinguished in the study (behaviours and risks) where Poland occupied the last but one position among the analyzed countries.

The results of linear ordering show visible disproportions between relatively rich Northern and Western Europe and the countries of Southern and Central Europe. Therefore, one can assume that there is a certain connection between the level of children's well-being and affluence of a country (the connection with GDP per capita), although some deviations from this tendency may be observed. Particularly in Great Britain child well-being is worse whereas in Slovenia and the Netherlands it is much better than this indicated by their level of affluence ${ }^{10}$.

The next stage of a comparative analysis of child well-being in Europe in the spatial approach was to determine the measure of development for particular countries, based on their distance from the so-called pattern of development (Figure 1). The basis of research 
procedure was the final set of diagnostic variables which were normalized. Hypothetical object $Q$ representing maximum values of transformed variables was assumed to be a pattern of development. Euclidean distance was accepted as a measure of distance of the analyzed territorial units from the pattern ${ }^{11}$.

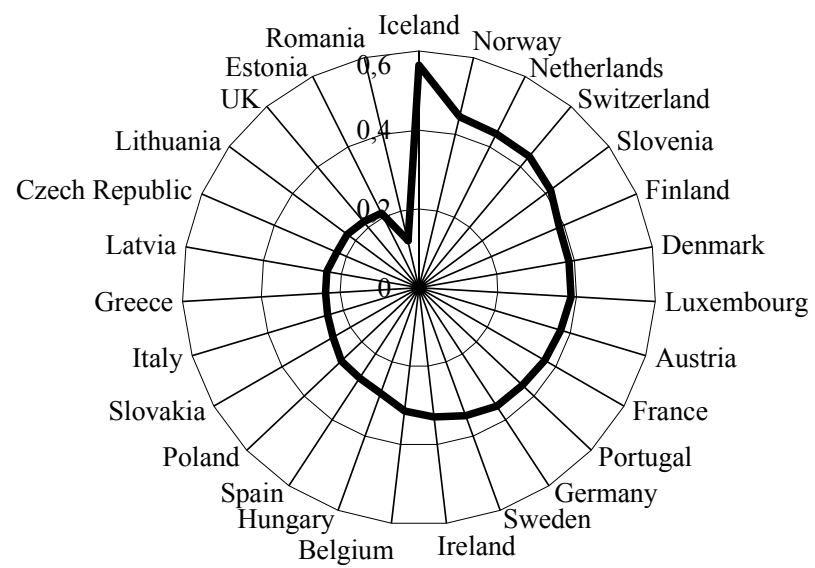

Fig. 1. Child well-being in the chosen countries of Europe according to the method of pattern of development

Source: own calculations.

The results of linear ordering of the countries using the pattern of development method confirmed the results obtained by means of synthetic non-pattern measures of the level of child well-being.

Children from Northern Europe (Iceland, Norway, Finland and Denmark) and also from the Netherlands, Switzerland and Slovenia, have the most favorable living conditions. Romania, the Baltic states, Great Britain and the Czech Republic are most distant from the pattern. Poland (with the measure of development at the level of 0.27 ) occupied a distant 18th position among the studied countries of Europe, among others, behind Hungary and Spain and before Slovakia, Greece and Italy (Figure 1).

\subsection{Classification of European countries according to similarities in child well-being}

In this study on spatial differentiation of child well-being the classification of European countries was made by using the criterion based on the main statistical parameters (arithmetic mean and standard deviation) of synthetic measure $Z$. Further on cluster analysis was applied. 
The set of 27 European countries was divided into four groups including units with values of the synthetic measure of living conditions belonging to the following intervals:

$$
\begin{array}{ll}
\mathrm{G}_{1}: \mathrm{z}_{\mathrm{i}} \in\left\langle\overline{\mathrm{z}}+\mathrm{s}_{\mathrm{z}} ; \max \left(\mathrm{z}_{\mathrm{i}}\right)\right\rangle, & \mathrm{G}_{2}: \mathrm{z}_{\mathrm{i}} \in\left\langle\overline{\mathrm{z}} ; \overline{\mathrm{z}}+\mathrm{s}_{\mathrm{z}}\right\rangle, \\
\mathrm{G}_{3}: \mathrm{z}_{\mathrm{i}} \in\left\langle\overline{\mathrm{z}}-\mathrm{s}_{\mathrm{z}} ; \overline{\mathrm{z}}\right\rangle, & \mathrm{G}_{4}: \mathrm{z}_{\mathrm{i}} \in\left\langle\min \left(\mathrm{z}_{\mathrm{i}}\right) \overline{\mathrm{z}}-\mathrm{s}_{\mathrm{z}}\right\rangle .
\end{array}
$$

The grouping was conducted for both variants of the synthetic measure and the results of the analysis are presented in Table 4.

Table 4. Classification of European countries according

\begin{tabular}{|c|c|c|c|c|c|}
\hline \multirow{2}{*}{ Group } & \multicolumn{2}{|c|}{ Variant of synthetic variable $Z$} & \multirow{2}{*}{ Group } & \multicolumn{2}{|c|}{ Variant of synthetic variable $Z$} \\
\hline & $z_{i}$ & $z_{i}^{\prime}$ & & $z_{i}$ & $z_{i}^{\prime}$ \\
\hline \multirow{7}{*}{$\mathrm{G}_{1}$} & & Finland & \multirow{9}{*}{$\mathrm{G}_{3}$} & Belgium & Belgium \\
\hline & Iceland & Iceland* & & Czech Republic & Czech Republic \\
\hline & & Luxembourg & & Greece & Greece \\
\hline & Netherlands & Netherlands & & Hungary & Hungary \\
\hline & Norway & Norway & & Ireland & Ireland \\
\hline & Slovenia & Slovenia & & Italy & Italy \\
\hline & & Switzerland & & Poland & Poland \\
\hline \multirow{9}{*}{$\mathrm{G}_{2}$} & \multirow{9}{*}{$\begin{array}{l}\text { Austria } \\
\text { Denmark } \\
\text { Finland } \\
\text { France } \\
\text { Germany } \\
\text { Luxembourg } \\
\text { Portugal } \\
\text { Sweden } \\
\text { Switzerland }\end{array}$} & \multirow{3}{*}{$\begin{array}{l}\text { Austria } \\
\text { Denmark }\end{array}$} & & Slovakia & Slovakia \\
\hline & & & & Spain & Spain \\
\hline & & & & Estonia & Estonia \\
\hline & & France & & Latvia & Latvia \\
\hline & & Germany & & Lithuania & Lithuania \\
\hline & & & $\mathrm{G}_{4}$ & Romania & Romania \\
\hline & & Portugal & & UK & UK \\
\hline & & Sweden & & & \\
\hline & & & & & \\
\hline
\end{tabular}
to the value of synthetic measure of child well-being

Source: own calculations.

Having analyzed the obtained specification, the authors found a significant convergence in the results of classification of European countries for both variants of the synthetic measure. The first group of countries with the best living conditions for children is constituted by Iceland and Norway and also the Netherlands and Slovenia (with the second variant of SM also Finland, Luxembourg and Switzerland). The second group is also created by the countries characterized by a high level of child well-being, exceeding Europe's average, among others the countries of Northern Europe (Denmark, Sweden) and also Austria, France, Germany and Portugal. Poland, 
like the remaining countries of Central and Southern Europe, Ireland and Belgium is placed in the group where child well-being is relatively worse $\left(\mathrm{G}_{3}\right)$. The least favorable situation is observed in Romania, Great Britain and the Baltic states.

The obtained specification of countries shows a positive skew of distribution of the synthetic measure of child well-being in Europe. Worth emphasizing is the fact that among the countries with the best well-being of children relatively small states dominate $\left(\mathrm{G}_{1}\right.$ group includes approximately $5-6 \%$ of the population of the studied area of Europe) whereas 14 states which occupy the lowest position in the classification (groups $G_{3}$ and $G_{4}$ ) are inhabited by almost $58 \%$ of the population of the analyzed area.

Another instrument used in the research to distinguish the countries with a similar level of child well-being was cluster analysis - grouping methods based on taxonomic similarity of multi-feature objects. The main aim of cluster analysis is division of $n$ set of objects described by many features into two or more separate homogeneous groups ${ }^{12}$.

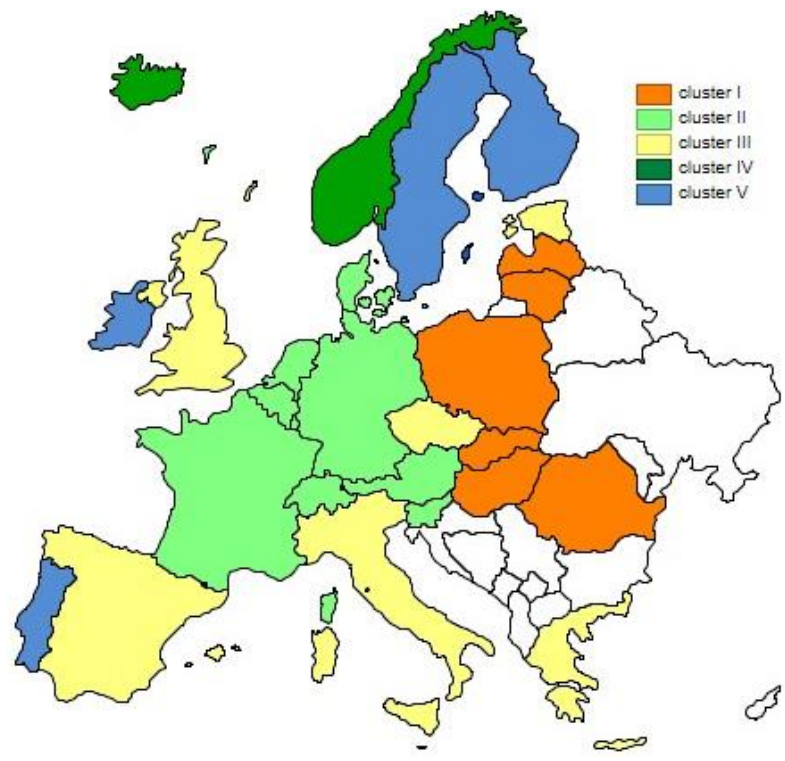

Fig. 2. Results of grouping of European countries according to similarity of child well-being (Ward's method)

Source: own calculations by means of STATISTICA 10.0.

In our research into spatial differentiation of child well-being in Europe, the set of 14 final diagnostic variables was accepted as a basis for the cluster analysis. These variables were 
normalized according to D. Strahl proposal. The cluster analysis was conducted by means of Ward's method. This method was chosen due to the fact that its effectiveness is emphasized in the related literature thanks to estimating the distances between clusters using variance analysis $^{13}$. In order to create the matrix of distances between the analyzed objects Euclidean distance was used. The border level of distances between the joined groups of similar objects, which showed the expected final number of clusters, was determined at the level of $50 \%$ of the maximum distance.

Ward's method used in the study allowed to differentiate five clusters of countries characterized by relatively similar conditions of child well-being (Figure 2). The first cluster consists of the countries of the so-called New Union (including Poland) which are characterized by relatively poor living conditions of children, above all in the economic and widely understood health aspects. Separate groups were constituted by highly developed West European countries and Slovenia (cluster II) and also two Northern countries of relatively good child well-being (cluster IV). Group III is strongly differentiated in respect of geography. This group includes both Great Britain and Estonia and the countries of Southern Europe, i.e. the countries where child well-being was also below the European average (Table 4).

\section{Conclusions}

Summing up our considerations, it should be stated that the European countries differ significantly as regards child well-being. There exists considerable stratification, above all between Northern and Western Europe on the one hand and the South of the continent and the countries of Central-Eastern Europe. Moreover, as proved by the research, those disproportions have not been clearly improved over the last few years ${ }^{14}$. Thus there is still much to do to accomplish the resolutions of the Convention on the Rights of the Child which, among others, state that: "States Parties shall ensure to the maximum extent possible the survival and development of the child" 15 .

Finally, it should be underlined that the questions about the scope of widely understood well-being of such a specific group as children, or about the selection of those dimensions of their existence which should be included in the study, still remain unanswered. Another problem is accessibility of statistical indicators concerning the distinguished research area which (taking into account their validity and comparability on the international scale) are still relatively scarce $^{16}$. 


\section{Notes}

${ }^{1}$ United Nations (1989).

${ }^{2}$ Richardson, Hoelscher, Bradshaw (2008); Bradshaw, Richardson (2009); Martorano et.al (2013).

${ }^{3}$ Mynarski (1992), p. 117.

${ }^{4}$ Zeliaś (2000), p. 37.

${ }^{5}$ Hellwig (1981).

${ }^{6}$ Ostasiewicz (2004), p. 23.

7 Ibidem, p. 24.

${ }^{8}$ Strahl (1984).

${ }^{9}$ Grabiński (1985).

${ }^{10}$ Bradshaw, Richardson (2009), p. 348.

11 Dudek, Krawiec, Landmesser (2011), p. 87.

12 Stanisz (2007), p. 114.

13 Hair et. al (1998), p. 496.

14 Martorano et.al (2013).

15 United Nations (1989).

16 UNICEF (2013).

\section{References}

Bradshaw, J. \& Richardson, D. (2009). An Index Of Child Well-being In Europe. Child Indicators Research, 2 (3), 319-351. DOI: 10.1007/s12187-009-9037-7.

Currie, C., Zanotti, C., Morgan, A., Currie, D., de Looze, M., Roberts, Ch., Samdal, O., Smith, O.R.F. \& Barnekow, V. (2012). Social determinants of health and well-being among young people. Health Behaviour in School-aged Children (HBSC) study: international report from the 2009/2010 survey. Copenhagen: WHO Regional Office for Europe.

Dudek, H., Krawiec, M. \& Landmesser, J. (2011). Podstawy analizy statystycznej w badaniach rynku. Warszawa: Wydawnictwo SGGW.

Grabiński, T. (1985). Metody określania charakteru zmiennych w wielowymiarowej analizie porównawczej. Zeszyty Naukowe Akademii Ekonomicznej w Krakowie, nr 213, 35-63.

Hair, J.F. jr, Anderson, R.E., Black, W.C. \& Tatham, R.L. (1998). Multivariate data analysis 5th ed. New Jersey: Prentice-Hall International.

Hellwig, Z. (1981). Wielowymiarowa analiza porównawcza i jej zastosowanie w badaniach wielocechowych obiektów gospodarczych. In: Ed. W. Welfe. Metody i modele ekonomiczno-matematyczne $w$ doskonaleniu zarzadzania gospodarka socjalistyczna (pp. 46-68). Warszawa: PWE. 
Martorano, B., de Neubourg, C., Natali, L. \& Bradshaw, J. (2013). Child Well-being in Economically Rich Countries: Changes in the first decade of 21st century. Working Paper 2013-02, Florence: UNICEF Office of Research.

Mynarski, S. (1992). Badania przestrzenne rynku i konsumpcji: przewodnik metodyczny. Warszawa: PWN.

Ostasiewicz, W. (2004). Ocena i analiza jakości życia. Wrocław: Wydawnictwo Akademii Ekonomicznej we Wrocławiu.

Richardson, D., Hoelscher, P. \& Bradshaw, J. (2008). Child Well-Being in Central and Eastern European Countries (CEE) and the Commonwealth of Independent States. Child Indicators Research, 1 (3), 211-250. DOI: 10.1007/s12187-008-9020-8.

Stanisz, A. (2007). Przystęny kurs statystyki z wykorzystaniem STATISTICA PL na przykładach z medycyny. Tom 3. Analizy wielowymiarowe. Kraków: StatSoft.

Strahl, D. (1984). Metody ekonometryczne w prognozowaniu rozwoju przemystu. Wrocław: Wydawnictwo AE we Wrocławiu.

UNICEF Office of Research (2013). Child Well-being in Rich Countries: A comparative overview. Innocenti Report Card 11, Florence: UNICEF Office of Research.

United Nations (1989). Convention on the Rights of the Child (CRC). Geneva: United Nations.

Zeliaś, A. (2000). Taksonomiczna analiza przestrzennego zróżnicowania życia w Polsce w ujęciu dynamicznym. Kraków: Wydawnictwo Akademii Ekonomicznej w Krakowie. 